\title{
HOST PREFERENCE OF RED PUMPKIN BEETLE IN A CHOICE TEST UNDER NET CASE CONDITION
}

\author{
M. M. H. Khan, M. Z. Alam ${ }^{1}$ and M. M. Rahman ${ }^{1}$ \\ Department of Entomology, Patuakhali Science and Technology University, \\ Gumki, Patuakhali, Bangladesh
}

The red pumpkin beetle (RPB), Aulacophora foveicollis Lucas (Coleoptera: Chrysomelidae) is a common and serious pest of a wide range of cucurbits, such as ash gourd (Benincasa hispida), pumpkin (Cucurbita pepo L.), tinda (Citrullus vulgaris var. fisulosus), ghia tori (Luffa aegyptica), cucumber and melon (Atwal (1993). Both larval and adult stages are injurious to the crop and cause severe damage to almost all cucurbits at seedling stage. They feed underside of cotyledonous leaves by making holes into them. Losses due to infestation are quite evident which may reach up to $35-75 \%$ at seedling stage (Yamaguchi 1983). The RPB is a pest of pumpkins, musk melons and bottle gourds, but it appears to be able to feed on any cucurbits (Rahman and Annadurai 1985). Butani and Jotwani (1984) reported that this beetle is a polyphagous insect and prefers cucurbit vegetables and melons. Some leguminous crops are also their main alternate hosts. According to Begum (2002), among five cucurbits (viz., sweet gourd, ash gourd, sponge gourd, snake gourd and cucumber) sweet gourd is identified as the most susceptible and highly preferred host to RPB and cucumber is recognized as less susceptible and preferred host to the pest. In present study an attempt was made to observe host preference of RPB on different cucurbits and to determine leaf area damage caused by RPB on cucurbits.

The experiment was conducted in a choice test under confined condition in a net cage (a circular disc of $3.8 \mathrm{~m}$ diameter made of hardboard). It looked like a large cylindrical dish of $3.8 \mathrm{~m}$ diameter and $70 \mathrm{~cm}$ height. Five bamboo sticks $(45 \mathrm{~cm})$ were tightly fixed with the edge of the dish to hold the mosquito net at the top and surrounding the dish. The entire dish was covered with a nylon mosquito net and was tightly bound around the dish with the help of a nylon rope. The experiments were conducted at $21.5-23.5{ }^{\circ} \mathrm{C}$.

Ten cucurbitaceous crops (viz. sweet gourd, bottle gourd, ash gourd, bitter gourd, sponge gourd, ribbed gourd, snake gourd, cucumber, khira and muskmelon) were grown in polyethylene bags containing a mixture of soil, manure and fertilizers. Fifteen day old seedlings of each cucurbit were placed in the net cage maintaining $15 \mathrm{~cm}$ distances. Sixty adults of RPB (30 males and 30 females) were placed at the centre of a plastic pot. The pot containing the

2Department of Entomology, Bangabandhu Sheikh Mujibur Rahman Agricultural University, Gazipur, Bangladesh. 
beetles was placed in the net cage and the beetles were released by removing the lid of the pot and were allowed them to feed on the cucurbit seedling according to their choice. The experiment was conducted with three replications (cages) during the period from 26 February to 6 March 2008.

Data were recorded at 1, 6, 12, 24 and 48 hours after release (HAR). The movement of beetles towards each cucurbit plants and feeding activities were recorded. The beetles fed on the leaves of respective cucurbit plants. The leaf area damaged by RPB in each cucurbit was estimated after 48 HAR. Analyses were made accordingly.

Under confined condition in the mosquito net cage, bitter gourd was made free from RPB infestation. At 1, 6, 12 and 24 hours after release, RPB population was found highest on sweet gourd. At 48 HAR the highest peak was found on muskmelon. The population of RPB on those two crops was significantly different only at 6 HAR. The populations of RPB on ashgourd, ribbed gourd, cucumber and khira ranged 1.00-3.33, 0.00-2.00, 0.67-1.67 and 0.00-2.00 per two plants, respectively. Three crops (Sweet gourd, musk melon and ashgourd) may be noted as highly preferred hosts of RPB. Bitter gourd was free from infestation and it was noted as non-preferred host. On khira and cucumber average population of RPB was 1.07-1.53 per two plants. On other cucurbits, population of RPB was less than one (Table 1).

Table 1. Population of red pumpkin beetle feed on cucurbit hosts under confined condition in a mosquito net cage.

\begin{tabular}{lcccccc}
\hline \multirow{2}{*}{ Cucurbit host } & \multicolumn{5}{c}{ Number of adult RPB settled per two plants observed at various hours } \\
& \multicolumn{7}{c}{\begin{tabular}{c} 
after release (HAR) \\
\cline { 2 - 7 }
\end{tabular}} & HAR & HAR & HAR & HAR & HAR & Mean \\
\hline Sweet gourd & $2.33 \mathrm{a}$ & $4.00 \mathrm{a}$ & $3.00 \mathrm{a}$ & $4.00 \mathrm{a}$ & $4.67 \mathrm{ab}$ & 3.60 \\
Bottle gourd & $0.00 \mathrm{c}$ & $0.67 \mathrm{bc}$ & $0.33 \mathrm{~b}$ & $0.33 \mathrm{~cd}$ & $0.00 \mathrm{e}$ & 0.27 \\
Ash gourd & $1.00 \mathrm{bc}$ & $2.00 \mathrm{ab}$ & $2.67 \mathrm{a}$ & $3.33 \mathrm{ab}$ & $2.67 \mathrm{bc}$ & 2.33 \\
Bitter gourd & $0.00 \mathrm{c}$ & $0.00 \mathrm{c}$ & $0.00 \mathrm{~b}$ & $0.00 \mathrm{~d}$ & $0.00 \mathrm{e}$ & 0.00 \\
Sponge gourd & $0.33 \mathrm{bc}$ & $0.33 \mathrm{bc}$ & $0.67 \mathrm{~b}$ & $1.00 \mathrm{~cd}$ & $0.00 \mathrm{e}$ & 0.47 \\
Ribbed gourd & $0.67 \mathrm{bc}$ & $0.00 \mathrm{c}$ & $0.00 \mathrm{~b}$ & $2.00 \mathrm{abc}$ & $0.33 \mathrm{de}$ & 0.60 \\
Snake gourd & $0.00 \mathrm{c}$ & $0.33 \mathrm{bc}$ & $0.00 \mathrm{~b}$ & $0.00 \mathrm{~d}$ & $0.33 \mathrm{de}$ & 0.13 \\
Cucumber & $1.00 \mathrm{bc}$ & $0.67 \mathrm{bc}$ & $1.67 \mathrm{ab}$ & $1.33 \mathrm{bcd}$ & $2.00 \mathrm{bcd}$ & 1.53 \\
Khira & $0.00 \mathrm{bc}$ & $2.00 \mathrm{ab}$ & $0.33 \mathrm{~b}$ & $1.67 \mathrm{abcd}$ & $0.33 \mathrm{de}$ & 1.07 \\
Muskmelon & $1.33 \mathrm{ab}$ & $1.33 \mathrm{bc}$ & $1.67 \mathrm{ab}$ & $3.67 \mathrm{ab}$ & $6.00 \mathrm{a}$ & 2.80 \\
\hline
\end{tabular}

Means within the same column having a common letter (s) do not differ significantly $(\mathrm{p}=0.05)$ by DMRT. Analysis was performed after square root transformation $\{\sqrt{ }(\mathrm{x}+0.5)\}$ of the original values. Values are means of three replications

Accordingly the highest percentage of leaf area damage per plant was observed on musk melon leaves followed by sweet gourd and ash gourd. The 
lowest percentage of leaf area damage was found on snake gourd followed by sponge gourd and bottle gourd (Fig. 1).

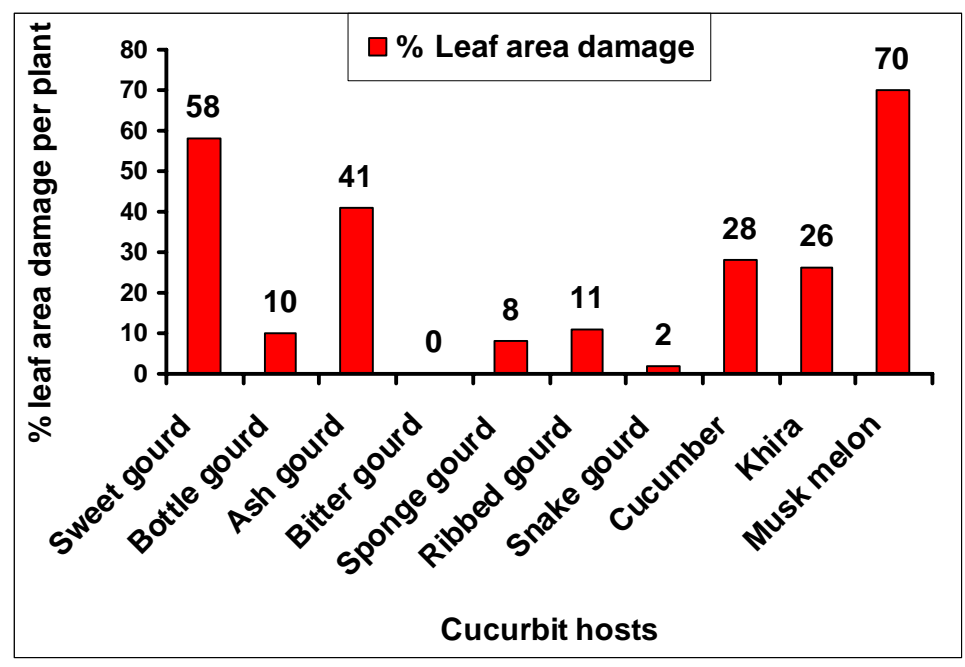

Fig. 1. Percentage of leaf area damage by RPB under confined condition in a net cage.

This insect showed different preference for various host species. Sweetgourd (pumpkin), Cucurbita maxima Duch. was the preferred host (Fig. 1). The present result is in agreement with the findings of Roy and Pande (1991), Bogawat and Pandey (1967) and Khan and Hajela (1987). Non- feeding on bitter gourd or negligible feeding on snake gourd are supported by Bogawat and Pandey (1967) and Khan and Hajela (1987). According to York (1992) triterpenoid compound from bitter gourd was found to inhibit feeding of red pumpkin beetle adults completely on cucurbit leaves. Dhillon and Sharma (1989) observed significant differences for resistance to red pumpkin beetle in summer squash both in the field and cage experiments. A significant phenotypic correlation indicated that there was good agreement between field rating and cage reactions following insect feeding (Dhillon and Sharma 1989). However, Rawat and Mehra (1967) found normal feeding on bitter gourd and snake gourd. Alikhan and Yousuf (1985) found normal feeding of RPB on bitter gourd.

In the present study sweet gourd and musk melon were found to be the most preferred host of red pumpkin beetle and bitter gourd was found as nonpreferred host of RPB. The highest percentage of leaf area damage per plant was observed on musk melon leaves followed by sweet gourd and ash gourd. The lowest percentage of leaf area damage per plant was on snake gourd leaves followed by sponge gourd and bottle gourd. 


\section{LITERATURE CITED}

ALIKHAN, M.A. and YOUSUF, M. 1985. Effect of host on the oviposition and development and survival of the larvae of Aulacophora foveicollis (Lucas) (Chrysomelidae: Coleoptera). Canadian J. Zool. 63: 1634-7.

ATWAL, A.S. 1993. Agricultural Pests of India and South East Asia. Kalyani Publ. New Delhi, Ludhiana. pp. 189-190.

BEGUM, L.A.A. 2002. Host preference of fruit fly and red pumpkin beetle to different cucurbit vegetables grown in summer. M.S. Thesis. Department of Entomology. BSMRAU, Gazipur, Bangladesh. 65p.

BOGAWAT, J. K. and PANDEY, S. N. 1967. Food preference in Aulacophora sp. Indian J. Ent. 29(4): 349-352.

BUTANI, D.K. and JOTWANI, M.G. 1984. Insects in Vegetables. Periodical Expert Book Agency. Vivek-Vihar, Delhi, India. pp. 356.

DILLON, N. P. S. and SHARMA, B. R. 1989. Relationship between field and cage assessments for resistance to red pumpkin beetle in summer squash. Euphytica. 40: 63-65.

KHAN, M. Z. and HAJELA, K. P. 1987. Studies on Aulacophora foveicollis Lucas (Coleoptera: Chrysomelidae)-Food preference and extent of damage. Indian J. Ent. 49(4): 457-459.

RAHMAN, K. and ANNADURAI, R.S. 1985. Host selection and food utilization of the red pumpkin beetle, Raphidopalpa foveicollis (Lucas) (Chrysomelidae: Coleoptera). Proc. Indian Acad. Sci. Anim. Sci. 94: 547-556.

RAWAT, R.R. and MEHRA, C.K. 1967. Host preference of pumpkin beetles, Raphidopalpa foveicollis (Lucas) and Aulacophora intermedia Jacoby (= atripennis Fabr.). Journal, Jawaharlal Nehru Krishi Vishwa Vidyalaya, Jabalpur. 1: 127-30.

ROY, D.C. and PANDE, Y.D. 1991. Seasonal incidence, host preference and feeding rate of red pumpkin beetle (Raphidopalpa foveicollis) in Tripura. Indian J. Agric. Sci. 61(8): 603-607.

STEEL, R. G. D. and TORRIE, J.H. 1960. Principles and Procedures of Statistics. McGraw Hill Book Co. Inc., New York. 481 p.

YAMAGUCHI, M. 1983. World Vegetables. Dept. of Vegetable Crop, Univ. of California. 415 p.

YORK, A. 1992. Pest of cucurbit crops: Marrow, pumpkin, squash, melon and cucumber. In: Vegetable Crop Pests. Mckinlay, R.G. (ed.). McMillan Press. Houndmills, Basingstoke, Hampshaire, and London. pp. 139-161.

(Manuscript received on May 4, 2011; revised on December 20, 2011) 